\title{
Use of Media Zoom to Improve Thematic Learning Results About Night-Night Activities In Class 1 Students
}

\author{
Dhesi Purnamasari
}

SDN TAMBAKREJA 07

dhesipurnamasari@gmail.com

\section{Article History}

accepted $14 / 11 / 2020$

\begin{abstract}
The purpose of this research is to improve student learning outcomes in thematic material about night activities. This research is a classroom action research (PTK) which is carried out in two cycles, each cycle consisting of planning, implementation, observation, and reflection stages. The subjects of this study were the first grade students of SDN Tambakreja 07 in the 2020/2021 academic year, totaling 28 students. Data collection techniques using observation and tests. Data analysis includes data reduction, data presentation, and drawing conclusions. Research shows that the use of Zoom media can improve student learning outcomes on thematic material about nighttime activities in class I SDN Tambakreja 07 academic year 2020/2021 as evidenced by the percentage of completeness of learning outcomes in cycle l of $53.57 \%$ to $75 \%$ in cycle II . Keywords: Zoom, Thematic, Student
\end{abstract}

\section{Abstrak}

Tujuan penelitian ini adalah meningkatkan hasil belajar siswa pada materi Tematik tentang Kegiatan Malam Hari. Penelitian ini merupakan penelitian tindakan kelas (PTK) yang dilaksanakan dalam dua siklus, setiap siklus terdiri dari tahap perencanaan, pelaksanaan, observasi, dan refleksi. Subjek penelitian ini adalah peserta didik kelas I SDN Tambakreja 07 tahun pelajaran 2020/2021 yang berjumlah 28 peserta didik. Teknik pengumpulan data menggunakan observasi dan tes. Analisis data meliputi reduksi data, penyajian data, dan penarikan kesimpulan. Penelitian menunjukkan bahwa penggunaan media Zoom dapat meningkatkan hasil belajar siswa pada materi Tematik tentang Kegiatan Malam Hari di kelas I SDN Tambakreja 07 tahun pelajaran 2020/2021 yang dibuktikan dengan persentase ketuntasan hasil belajar pada siklus I sebesar $53,57 \%$ menjadi $75 \%$ pada siklus II Kata kunci: Zoom, Tematik, Siswa

Social, Humanities, and Education Studies (SHEs): Conference Series https://jurnal.uns.ac.id/shes

p-ISSN 2620-9284

e-ISSN 2620-9292 


\section{PENDAHULUAN}

Pendidikan adalah suatu usaha yang dilakukan dengan sadar oleh keluarga,masyarakat,atau pemerintah melalui bimbingan pengajaran atau pembelajaran dan pelatihan yang berlangsung baik dilakukan di sekolah maupun luar sekolah sepanjang hidup untuk mempersiapkan siswa agar dapat menjalankan perannya dalam lingkungan untuk masa yang akan dating (Edgar Dale).

Peran pendidikan sendiri adalah meningkatkan kualitas sumber daya manusia, mewujudkan kesejahteraan umum serta mencerdaskan kehidupan bangsa. Masyarakat yang berpendidikan tentu memiliki kualitas hidup yang lebih baik daripada yang tidak berpendidikan, kesejahteraan batiniah dan lahiriah juga mempengaruhinya. Bangsa yang cerdas tentu masyarakatnya memiliki

Sumber daya manusia yang berkualitas juga. Untuk itu belajar sangat penting bagi diri sendiri dan lingkungan sekitar. Pentingnya belajar untuk belajar (learning to learn) menumbuhkan sikap terbuka terhadap adanya perubahan dan tantangan globalisasi yang semakin modern dan menantang.

Dalam UU RI No. 20 Tahun 2003 tentang Sistem Pendidikan Nasional, pasal 1 menjelaskan pendidikan adalah usaha sadar dan terencana untuk mewujudkan suasana belajar dan proses pembelajaran agar peserta didik secara aktif mengembangkan potensi dirinya untuk memiliki kekuatan spiritual keagamaan, pengendalian diri, kepribadian, kecerdasan, akhlak mulia, serta keterampilan yang diperlukan dirinya, masyarakat, bangsa dan negara (Departemen Pendidikan Nasional, 2014).

Untuk mewujudkan tujuan pendidikan itu maka kondisi pembelajaran yang kondusif sangat diperlukan dalam proses pembelajaran, kondisi yang kondusif diantaranya :

1. Proses pembelajaran berlangsung aktif interakif

2. Proses pembelajaran berlangsung komunikatif ( dua arah ) antara guru dan siswa saling komunikatif

3. Semangat dan motivasi belajar siswa tinggi

4. Hasil belajar Tematik siswa tinggi dibuktiktikan dengan siswa yang mencapai KKM lebih dari atau sama dengan 70.

Pada masa pandemi seperti sekarang ini, tujuan pendidikan haruslah tetap tercapai, pembelajaran yang kondusif juga harus tetap dilaksanakan demi mencapai tujuan pendidikan tersebut, akan tetapi pada kenyataannya pembelajaran pada daring pada masa sekarang ini menimbulkan berbagai permasalahan dan pembelajaran antara lain :

1. Pembelajaran daring yang selama ini diterapkan di SD Negeri Tambakreja 07 adalah masih menggunakan media whatsapp grup, sehingga pembelajaran kurang aktif dan interaktif

2. Pembelajaran cenderung pasif ( satu arah ) dan kurang komunikatif, karena tidak dapat mengecek siswa dalam pembelajaran secara langsung

3. Kenyataannya SD Negeri Tambakreja 07 belum menggunakan media yang mampu meningkatkan keaktifan siswa

4. Hasil pengamatan awal menunjukan bahwa siswa kelas 1 SD Negeri Tambakreja 07 belum memiliki semangat belajar yang tinggi yang mampu meningkatkan hasil belajar siswa.

5. Hasil belajar siswa masih rendah selama pembelajaran daring dengan menggunakan media whatsapp karena jumlah siswa yang dapat mencapai KKM pada pelajaran Tematik belum mencapai $70 \%$

Berbagai upaya peningkatan hasil belajar siswa telah dilakukan guru, namun belum mencapai hasil yang maksimal, karena belum menggunakan

media yang memiliki potensi untuk meningkatkan motivasi siswa, keaktifan siswa yang nantinya juga akan meningkatkan hasil belajar siswa. Berdasarkan hasil kajian 
pustaka menemukan bahwa media Zoom berpotensi untuk meningkatkan kompetensi hasil belajar siswa.

Untuk memperbaiki proses belajar, meningkatkan hasil belajar siswa, aka pembelajaran daring di SD Negeri Tambakreja 07 akan menerapkan pembelajaran menggunakan media Zoom . Setelah tindakan ini dilakukan diharapkan :

1. Tingkat keaktifan siswa dalam pembelajaran meningkat

2. Tingkat interaksi motivasi belajar siswa dalam pembelajaran meningkat

3. Hasil belajar Tematik siswa meningkat, dengan persentase jumlah siswa yang mencapai kriteria ketuntasan minimal meningkat khususnya hasil belajar Tematik, menjadi $75 \%$

\section{METODE}

Penelitian ini merupakan penelitian tindakan kelas (PTK) yang dilaksanakan dalam dua siklus, setiap siklus terdiri dari tahap perencanaan, pelaksanaan, observasi, dan refleksi. Subjek penelitian ini adalah peserta didik kelas I SDN Tambakreja 07 Cilacap tahun pelajaran 2020/2021 yang berjumlah 28 peserta didik.

Data yang dianalisis berupa data kualitatif yaitu penggunaan kuantitatif yaitu hasil belajar Tematik peserta didik. Teknik pengumpulan data menggunakan tes. Uji validitas data menggunakan triangulasi teknik dan triangulasi sumber. Analisis data meliputi reduksi data, penyajian data, dan penarikan kesimpulan.

\section{HASIL DAN PEMBAHASAN}

Penerapan Media Zoom dalam pembelajaran Tematik meliputi langkah-langkah: (1) Guru menyusun perangkat pembelajaran. Guru membuat powerpoint yang berisi materi yang akan disampaikan pada kegiatan pembelajaran melalui Zoom (2) Guru menjelaskan cara penggunaan Zoom terlebih dahulu kepada siswa dan orang tua murid (3)Guru menjelaskan materi pelajaran pada semua peserta didik melalui media Zoom(4) Guru mengamati aktivitas belajar dan memberi penilaian kompetensi (5) Guru, tutor, dan peserta didik memberikan evaluasi proses belajar mengajar untuk menetapkan tindak lanjut.

Hasil penelitian menunjukkan peningkatan hasil belajar pada materi Kegiatan Malam Hari. Terlihat pada tabel berikut

Peningkatan hasil belajar Tematik peserta didik pada materi Kegiatan Malam Hari diukur dengan menggunakan hasil belajar siswa. Teknik tes hasil belajar dengan instrument lembar soal evaluasi. Teknik pengumpulan data hasil belajar peserta didik diterapkan disetiap

Aspek yang diukur yaitu aspek kognitif atau pengetahuan yang terdiri dari mengingat (C1), memahami (C2), mengaplikasi (C3), dan menganalisis (C4) yang diukur berdasarkan hasil evaluasi setelah mengikuti pembelajaran dengan penggunaan media Zoom pada materi Kegiatan Malam Hari

Penggunaan media Zoom dalam pembelajaran Tematik dapat meningkatkan hasil belajar peserta didik di kelas I SDN Tambakreja 07 Cilacap secara signifikan. Pada hasil Penilaian sebelumnya terdapat 15 dari 28 peserta didik yang belum mencapai KKM dengan persentase ketuntasan hasil belajar hanya 40,30\%. Setelah dilakukan tindakan, persentase ketuntasan hasil belajar pada siklus I meningkat menjadi $53,57 \%$. Pada siklus II terjadi peningkatan menjadi $75 \%$. Berdasarkan analisis hasil belajar peserta didik setelah pelaksanaan tindakan, dapat diambil kesimpulan bahwa penggunaan media zoom dapat meningkatkan hasil belajar Tematik pada materi Kegiatan Malam Hari. Hal ini sesuai dengan hasil penelitian yang dilakukan oleh Briggs(1977) membuktikan bahwa media pembelajaran dapat meningkatkan hasil belajar Tematik tentang kegiatan malam hari siswa SDN Tammbakreja 07 Cilacap secara signifikan. Hasil penelitian ini juga memperkuat pendapat National Education 
Association (1969) bahwa media pembelajaran berpengaruh baik pada proses pembelajaran dan hasil belajar meningkat secara signifikan.

\section{SIMPULAN}

Berdasarkan hasil penelitian dan uraian pembahasan maka dapat diambil simpulan sebagai berikut.

Penggunaan media Zoom untuk meningkatkan hasil belajar Tematik pada materi Kegiatan Malam Hari kelas I SDN Tambakreja 07 Cilacap Tahun Pelajaran 2020/2021 dilaksanakan dengan langkah-langkah (1) Guru menyusun perangkat pembelajaran. Guru membuat powerpoint yang berisi materi yang akan disampaikan pada kegiatan pembelajaran melalui Zoom (2) Guru menjelaskan cara penggunaan Zoom terlebih dahulu kepada siswa dan orang tua murid; (3) Guru menjelaskan materi pelajaran pada semua peserta didik melalui media Zoom; (4) Guru mengamati aktivitas belajar dan memberi penilaian kompetensi. (5) Guru, tutor, dan peserta didik memberikan evaluasi proses belajar mengajar untuk menetapkan tindak lanjut.

Penggunaan media Zoom dapat meningkatkan hasil belajar Tematik pada materi Kegiatan Malam Hari di kelas I SDN Tambakreja 07 Cilacap tahun pelajaran 2020/2021 yang dibuktikan dengan rata-rata ketuntasan hasil belajar peserta didik pada siklus I meningkat menjadi $53,57 \%$. Pada siklus II terjadi peningkatan menjadi $75 \%$

\section{DAFTAR PUSTAKA}

Azhar Arsyad, Media Pengajaran, (Jakarta : Raja Grafindo Persada, 2000) h. 2 lbid, h.3

Azhar Arsyad, Media Pembelajaran. (Jakarta : Raja Grafindo Persada, 2007). h.4 lbid. h.15

Azhar Arsyad, Media Pembelajaran. (Jakarta : Raja Grafindo Persada, 2007), h.27

Media Pembelajaran, (Jakarta : Departemen Pendidikan Nasional Direktorat Jenderal Pendidikan Dasar dan Menengah Direktorat Tenaga Kependidikan, 2003). h. 17

Suharsimi Arikunto,Suhardjono \& Supardi. (2010). Penelitian Tindakan Kelas.Jakarta: Bumi Aksara 